\title{
A DRAFT CLASSIFICATION OF ATTRIBUTES IN KOREAN AND POLISH LANGUAGES
}

\author{
Anna BOROWIAK, $\mathrm{PhD}$ \\ Department of Korean Studies \\ Institute of Linguistics \\ Adam Mickiewicz University, Poznań, Poland \\ annaboro@amu.edu.pl
}

\begin{abstract}
Analyzing various classifications of sentence parts in Korean and Polish, it is easy to identify the existence of attributes in both of them, although the English term itself is not actually being used by Korean linguists, and thus might not be well known. Nevertheless, since the function of gwanhyeongeo (Kor. 관형어) in Korean, and attributes in Polish is similar, for the sake of transparency, this particular term will be used.

The aim of this article is to propose a comprehensive classification of attributes in both target languages based on formal, syntactic and semantic parameters. In order to do it in the most exhaustive way, firstly different approaches concerning the definition of attributes, as well as the methods of their classification, proposed by various linguists in both languages will be examined. The author hopes to find out to which extent the typological differences between Korean and Polish are reflected in the attributes' properties, according to which they can be classified.
\end{abstract}

Key words: Korean, Polish, attribute, property, parameter, classification 


\section{한국어와 폴란드어의 관형어 분류 초안}

논문초록: 한국어와 폴란드어에 각각 존재하는 다양한 문장 성분의 분류를 분석해 보면 양국 언어에서 관형어의 실재를 쉽게 확인할 수 있다. 'Attribute'란 용어 자체가 한국 언어학자들에 의해 실제로 사용되지 않음으로써 잘 알려져 있지 않지만, 한국어 문장에서 관형어의 기능은 폴란드어 문장에서의 'attribute'와 기능이 유사하기 때문에 연구의 명확성을 위해서 'attribute'라는 용어를 사용할 것이다.

본 연구의 목적은 두 언어에서의 형태적 - 통사적 · 의미적 매개 변수를 바탕으로 둔 포괄적인 관형어의 분류를 제안하는 데에 있다. 이 과제를 최대한 철저히 수행하기 위하여 먼저 한국과 폴란드의 여러 언어학자들이 관형어를 어떻게 정의하고 분류해 왔는지를 알아볼 것이다.

본고는 한국어와 폴란드어 간의 유형론적인 차이가 관형어의 속성을 분류하는 방법에 어느 정도 반영되는지를 밝혀 내고자 한다.

주제어: 한국어, 폴란드어, 관형어, 특질, 매개 변수, 분류

\section{ZARYS KLASYFIKACJI PRZYDAWEK W JĘZYKU KOREAŃSKIM I POLSKIM}

Streszczenie: Porównując różne klasyfikacje części zdania, istniejące w języku koreańskim i polskim, potwierdzimy występowanie przydawek. Pomimo, iż angielski termin określający przydawkę - 'attribute' nie jest stosowany przez koreańskich lingwistów, ze względu na podobieństwa gwanhyeongeo (kor. 관형어) w języku koreańskim i przydawkami w języku polskim oraz dla zachowania przejrzystości, termin ten będzie stosowany.

Celem niniejszego artykułu jest zaproponowanie klasyfikacji przydawek w języku koreańskim i polskim, opartej na parametrach formalnych, syntaktycznych oraz leksykalnych. Aby precyzyjnie scharakteryzować przydawki, najpierw zostaną przeanalizowane różne definicje tej części zdania oraz metody ich klasyfikacji, zaproponowane przez różnych koreańskich i polskich językoznawców. Autor żywi nadzieję, iż niniejsze badanie ujawni, do jakiego stopnia różnice typologiczne istniejące pomiędzy językiem koreańskim i polskim są odzwierciedlone we własnościach, według których przydawki w obu językach mogą zostać sklasyfikowane.

Stowa klucze: język koreański, język polski, przydawka, własność, parametr, klasyfikacja 


\section{Introductory Remarks}

Despite the genetic and structural differences between Korean and Polish language, the classifications of sentence parts reveal the existence of common attributes in both of them. There are however, some differences concerning the membership of sentence components in their subclasses.

In Korean language the sentence components are usually divided into the three following categories:

(i) the main parts of the sentence (juseongbun, Kor. 주성분) - a subject (jueo, Kor. 주어), an object (mokjeogeo, Kor. 목적어), a predicate (seosureo, Kor. 서술어) and a complement (boeo, Kor. 보어),

(ii) the subsidiary (or complementary) parts of the sentence, sometimes also called modifiers (busokseongbun, Kor. 부속성분) - (gwanhyeongeo, Kor. 관형어) and an adverbial (busaeo, Kor. 부사어) $)^{1}$,

(iii) the independent part of the sentence (dongnipseongbun, Kor. 독립성분) - (dongnibeo, Kor. 독립어) (cf. 남기심 and 고영근 2006, 나찬연 2007 etc.). ${ }^{2}$

It is worth mentioning that the subject literature published in Korean, including the one for foreign learners, despite providing English translation for all sorts of linguistic terms such as the names of the parts of speech, fail to give the corresponding terms for some names of the above sentence components. Even though the English equivalents concerning the main parts of the sentence are relatively

\footnotetext{
${ }^{1}$ Although the Korean term busok (Kor. 부속) can be translated as 'subsidiary, complementary, accessory' etc. in this article words, which modify the meaning of the superordinate word - namely attributes and adverbials, will be referred to as 'the secondary parts of the sentence', understood as the second most important sentence components after the main parts of the sentence. The term 'non-obligatory sentence components' could also be used, however, in some cases from semantic reasons attributes as well as adverbials have to be used, which means they would become obligatory sentence components and thus they would have to be excluded from this class.

${ }^{2}$ Some linguists such as 김광해 et al. (1999: 209) instead of three categories distinguish only two of them. Here the third category is simply included into the second one.
} 
frequently given (cf. 김기혁 2001, 나찬연 2007, 황경수 2009), those belonging to the last two classes are not. Nonetheless some scholars, such as 나찬연 (2007), took the attempt and translated the names of the secondary parts of a sentence into English as 'adnominal phrase' and 'adverbial phrase' respectively.

In the author's opinion however, both terms are not precise ones, since the attribute can be formed not only by a syntagma, but also by a single word, such as sae or yet (Kor. 새, 옛) meaning 'new' and 'old' respectively. This especially concerns attributes of Korean affiliation, represented by gwanhyeongsa (Kor. 관형사) usually referred to as a qualifier or a determinant. ${ }^{3}$ The adverbial can also be expressed by a single word only, e.g. dahaenghi or uyeonhi (Kor. 다행히, 우연히), meaning 'luckily' and 'accidently' respectively.

Among sentence components distinguished in Polish are: a subject, a predicate, an attribute, an object and an adverbial. It is worth to mention, that there are two kinds of objects, namely a direct and an indirect one. The first one is expressed in positive sentences in the accusative case, and in the negative sentences usually in the genitive case, rarely in the instrumental one. The indirect object is expressed with the dative, instrumental or locative case.

These components can be grouped into the main and the secondary parts of the sentence (Pol. główne i drugorzędne części zdania) (cf. Kokowski 1917: 5). Nevertheless the third category - the words outside of syntactic relations' (Pol. wyrazy w zdaniu poza związkami) is mentioned only by very few linguists, among them Klemensiewicz (1986: 132) and Podracki (1997: 186).

(i) the main parts of the sentence (Pol. główne części zdania) - a subject and a predicate,

(ii) the secondary parts of the sentence (Pol. drugorzędne części zdania) - an attribute, an object and an adverbial,

(iii) the words being outside of the syntactic relations in a sentence ${ }^{4}$.

\footnotetext{
${ }^{3}$ These bound forms are also called prenouns (cf. Lee and Ramsey 2000: 104-7) or adnouns (cf. Yeon and Brown 2011: 402). In this research however the term 'determiner' (Pol. determinant, określnik) will be used. In Author's opinion it is the most precise term.

${ }^{4}$ Podracki (1997: 188) explains that the term 'words outside of syntactic relations' should not be understood literally. Physically they are a part of a sentence as other
} 
Although both of the above classifications confirm that attributes are included into the secondary parts of the sentence, at the same they also reveal some differences concerning not only the syntactic categories of the components but also their membership in the subclasses of those classifications.

First of all, in Polish language only a subject and a predicate are included into the main sentence components, while in Korean an object and a complement also belong there. In both languages an attribute as well as an adverbial constitute the secondary parts of the sentence, however in Polish an object also belongs there.

Second of all, while an object in Polish can be divided into the direct and indirect one, in Korean only the first one is actually referred to as an object. Consequently, Polish indirect object is treated as a complement in Korean. There are, however, some differences between them too, in Polish both direct and indirect objects can be expressed by more than one case each, while Korean uses only one case to indicate an object, namely the allomorphic form of the accusative case (mokjeokgyeokjosa, Kor. 목적격조사) eul/reul (Kor. -을/를) and one allomorphic form for the complement (bogyeokjosa, Kor. 보격조사) -i/ga (Kor. -이/가). What is more, the form of just mentioned bogyeokjosa is identical with the nominative case particle (jugyeokjosa, Kor. 주격조사). It is also worthy to mention that the complement is used only when 'to become/ to be not (somebody/ something)' (Kor. '되다' and '아니다' respectively) are used as predicates.

In addition, in Korean unlike in Polish an interjection or an exclamation (Kor. 감탄사) as a part of speech becomes separately distinguished part of the sentence in Korean - called dongnibeo (Kor. 독립어). It is despite the fact that exclamations form in Polish one class of words and can constitute an independent utterance by themselves.

The aim of this article is to propose the set of parameters, according to which attributes in Korean and Polish language could be classified. Prior to dividing them into formal, syntactic and semantic ones, which systematize the properties that attributes possess - two aspects will be examined - namely (i) how Korean -

components do, their function is however different, and thus they are not contained in a sentence understood as a network of syntactic relations. 
and Polish scholars define the term attribute and how that definition has evolved over the years, and (ii) on the basis of what criteria this particular part of sentence is being classified. The Author hopes to find out to what extent the typological differences between Korean and Polish are reflected in the above-mentioned parameters, which could systematize the properties of attributes.

\section{An Attribute - Different Approaches Towards the Definition}

The term 'attribute' comes from Latin attributus, which is the past participle of attribuere meaning 'to attribute' composed of 'ad-' and 'tribuere' meaning 'to bestow'. Its first known usage dates back to the $14^{\text {th }}$ century (cf. Merriam-Webster Online Dictionary).

As far as the term 'attribute' is concerned, Korean linguists generally use one term, namely gwanhyeongeo (Kor. 관형어) (cf. 남광우, 이응백 and 이을환 1991, 김기혁 1996, 김광해 et al. 1999, 김기복 1999 , 김기혁 2001 , 임지룡 et al. 2005 , 남기심 and 고영근 $1985 / 2006$, 나찬연 2007, 김선효 2011, 오규환 2016 etc.). This term is also used in high school grammar books '고등학교문법' (2002/2005). However, in traditional grammar, either the term maegimmal (Kor. 매김말) (cf. 최현배 1937/1961; 김봉모 1978ab, 리의도 1982, 허웅 1983, 한길 1997 etc.) or maegim kkumimmal (Kor. 매김 꾸밈말) (최현배 1937/1961) is used. In North Korean linguistic terminology an attribute is called gyujeongeo (Kor. 규정어) (cf. 리동빈 1999/2004: 124, 우형식 2002: 309). 김기복 (1999) in the English abstract of his thesis uses the term 'attributive' while referring to attributes, while 한길 (1997) refers to the $m$ as the 'determinatives'. Curiously enough, despite the fact that the dictionary of applied linguistics by 박경자 et al. (2001) has e.g. 'attributive adjective' (Kor. 한정 형용사) and 'attributive use' (Kor. 한정적 사용) as its entries, the term 'attribute' is nowhere to be found. It is also noteworthy, that Korean grammar books published in Korean, despite providing English equivalents for all sorts of grammatical terms fail to give the one for 'attribute'. Foreign scholars, on the other hand in order to denote them use either the term 'attribute' (cf. Ramstedt, 1939: 34, 
$185)^{5}$, or 'modifier' (cf. Yeon and Brown 2011: 444; Martin 1992: $19)^{6}$.

Also in Polish language generally one term is being used, namely 'przydawka' (Eng. attribute). However, its Latin equivalent attributum (cf. Bańczerowski, Pogonowski and Zgółka 1982: 269) or polonised version of the word, namely 'atrybut' (cf. Arct 1899: 27, Nagórko 2005: 283) are also in use. Nevertheless some linguists such as Frankowska (1982) while referring to attributes prefer to use the term 'determiner' (Pol. determinator), which could in fact be treated as a hyperonym for both an attribute and an adverbial. In English books on Polish language either the term 'attribute' (Zagorska-Brooks 1975: 381-386), 'attributive modifiers' (Fisiak, Lipińska-Grzegorek, Zabrocki 1978:81) or "modifier'7 (Swan 1981: 4) are being used. ${ }^{8}$

\subsection{Definitions of Attributes in Korean}

The definition of what an attribute in Korean is, evolved with time. 최현배 (1937/1961: 757) defines it as 'something, which in order

5 Nevertheless it is referred to only in a short paragraph when discussing the indeclinable nature of nouns and their morphological structure. The author treats syntagmas such as 'a Korean house' (Kor. 조선 집) or 'a new house' (Kor. 새 집) as compounds, explaining that the preceding part, which remains unchanged, plays the attributive function.

${ }^{6}$ Yeon and Brown (2011: 444) use the term as the opposition to a complement, Martin (1992: 19) however, mentions it while explaining word spacing in Korean 'which reflects the potential pause between various constructions', among which he mentions those built from 'modifier and N' (e.g. 'such person', Kor. 그런 사람) and those built from 'modifier and quasi-free N' (e.g. 'such thing', Kor. 그런 것).

${ }^{7}$ It is worth to notice that the term 'modifier' can also be used while referring to adverbials.

${ }^{8}$ In Polish-Korean Dictionary compiled by 정병권 (2002: 703) the Polish term for 'attribute' is translated into Korean as 'a determiner such as adjective or adverb' (Kor. 한정사 - 형용사, 부사 따위), as 'a modifier' (Kor. 수식어) and as 'an adjunct' (Kor. 부가어). The mistranslation of the first term not only reveals the fact that the Polish term denoting one of the parts of the sentence was compared with Korean part of speech, but also that among attributes, apart from adjectives, adverbs are also enumerated, which should not take place. Although the attribute can be referred to as a modifier, it is worth to mention that not every adjunct really is an attribute. 
to describe parts of a sentence expressed with substantives ${ }^{9}$ (imjassi, Kor. 임자씨) is placed before the m'. 김봉모 (1978a: 19, 1978b: 50-1) indicates, that it not only describes the head but also limits its scope, which is considered to be the major property of attributes. It also forms the endocentric construction (naesim gujo, Kor. 내심 구조) ${ }^{10}$ with its head noun. 남광우, 이응백 and 이을환 (1991: 151) focus on their structure and explain that it is a substantive used with the genitive particle (referred there as 'the attributive particle').

김기복 (1999: 1-2) notices that the attribute is the secondary part of a sentence (and as such cannot become the major sentence component), which describes the following head, being one of the main parts of the sentence. He refers to three types of function an attribute can have, namely:

(i) the modifying function, which means the reduction of the scope denoted by the head itself or its properties (susik gineung, Kor. 수식 기능),

(ii) the static function (jeongtaejeok gineung, Kor. 정태적 기능) meaning that an attribute can only describe the state of the head and cannot become a predicate \{by itself\},

(iii) the indicative function (jisi gineung, Kor. 지시 기능).

He also points out that while it is clear that an attribute can describe the substantives (cheeon, Kor. 체언), it is not specified which word classes included by Korean linguists into the substantives - namely nouns, pronouns and numerals, can actually be modified by it. It is very important observation since despite the fact that so-called determinative attribute (gwanhyeongsa gwanhyeongeo, Kor. 관형사 관형어) can form a syntactic relation with its head noun, it cannot do the same with a pronoun or a numeral, regardless of the fact that all of the $\mathrm{m}$, as already mentioned, are in fact substantives in Korean.

\footnotetext{
${ }^{9}$ The term substantives cannot be replaced with the Latin term nomen. It is because in Korean it is used as a hyperonym of nouns, pronouns and numerals, while nomen as Gołąb et al. (1968: 379) point out, according to the terminology of the ancient grammarians, denotes a category of words with declension such as nouns, adjectives and numerals. Korean adjectives conjugate, as verbs do that is why using the abovementioned term nomen could be misleading.

10 김봉모 (1978b: 51) actually uses the term dongjungsim guseong (Kor. 동중심 구성).
} 
What is more, while the attributive forms (gwanhyeongsahyeong \{jeonseongeomi\}, Kor. 관형사형 \{전성어미\}) of verbs and adjectives can modify pronouns the $y$ cannot be used with numerals.

서정수 (1994) describes the syntactic and semantic nature of attributes by stating that the attribute as a modificant, forms a phrase with its head noun, pointing out that every attributive element, which modifies the head noun, is treated as an attribute. He also indicates that despite the fact that it is not a mandatory element of the NP, it complements or completes its meaning.

김기혁(2001: 337) focuses on the formal, syntactic and semantic properties of an attribute, by saying that this class is formed by determiners (gwanhyeongsa, Kor. 관형사), attributive forms of verbs and adjectives, and the substantives with the genitive case particle. Since attributes cannot be used by themselves, their usage requires the presence of the head, namely the modificand (pisusigeo, Kor. 피수식어).

남기심 and 고영근 (2006: 265) while defining the term 'attribute' refer to the syntactic category of the head it can modify, namely a subject or an object. They also point out that although it is not an obligatory part of a sentence [being the complementary part of the sentence] if the head is a bound noun their have to be used. 리의도 (1982: 123) notices that its function can be performed by various units, such as a word, a phrase or a clause (Kor. 낱말, 이은말, 마디 respectively, according to the terminology he uses).

한길 (1997: 6-8) strongly disagrees with widely accepted opinion that an attribute, unlike a subject or an object, neither directly affects a predicate nor it is under its grammatical influence, since as many scholars point out its influence is limited only to the head it describes. To prove his point and confirm that an attribute is 'indirectly lead by the predicate' he analyzes the aspect of honorification of the person appearing in attributes (attributive forms). ${ }^{11}$ However, above all, he also points out a very important criterion, which should also be taken into account while distinguishing

${ }^{11}$ Honorification in Korean is usually divided into: the subject honorification (Kor. 주체 높임), the object honorification (Kor. 객체 높임) and the hearer honorification (Kor. 상대 높입). 한길 convinces that apart from them the honorification of a person who appears in attributes (Kor. 매김말로 등장하는 사람 높임) should also be distinguished. 
attributes - namely the fact that the bigger focus should be placed on the type of words an attribute modifies, rather than on what sentence components do the y represent. In other words, it is not the part of the sentence being modified but the part of speech used as particular part of the sentence, which is being described, determines whether something is or is not the attribute. Consequently, if an attribute has a noun (or its equivalent e.g. the nominalized verb) as its head, it can modify every part of a sentence, namely: a subject, a direct object, a predicate (formed from a noun and a copula), a complement, another attribute, an adverbial or even an independent component of the sentence (Kor. 독립어). ${ }^{12}$ The distributional criteria in distinguishing attributes as well as their dependency on the head is also referred to by 한국방송통신 대학교 평생교육원 (2005: 138).

\subsection{Definitions of Attributes in Polish}

[In Indo-European languages] the attribute is usually defined as a word or phrase, which is syntactically subordinate to the word it describes and, which serves to limit, identify, particularize, describe, or supplement the meaning of the form [the head], it is in construction with. ${ }^{13}$ Zagorska-Brooks (1975: 831) specifies the head, which can be modified by the attribute - namely, a noun or nominal expressions.

The above definition however, is not precise, since it neither says to which word class the head ${ }^{14}$ belongs, nor what is its function

\footnotetext{
${ }^{12}$ E.g. a) 저 사람이 밥을 먹고 있다. That man is eating. (the subject)

b) 여자가 뜨거운 차를 마시고 있다. A woman is drinking a hot tea. (the direct object)

c) 수미가 영리한 학생이다. Sumi is a smart student. (the predicate - noun + copula)

d) 여동생이 훌륭한 의사가 되었다. My younger sister became an excellent doctor. (the complement)

e) 나는 그 사람의 자동차를 봤다. I saw this man's car. (another attribute)

f) 오빠가 좁은 마당에서 테니스를 치고 있다. My older brother is playing tennis in the narrow yard. (the adverbial)

g) 못난 사람아! You foolish/ stupid man! (the independent part of the sentence)

${ }^{13} \mathrm{cf}$. http://www.dictionary.com/browse/attribute (accessed August 13, 2016).

${ }^{14}$ In linguistic literature 'the head' is also called the determinatum, the modificand, the qualificatum, the qualified word or the superordinate word, while the terms
} 
in a sentence. Overlooking this particular prerequisite leads, without a question, to including e.g. adverbials into the category of attributes, since the y also, as syntactically subordinate sentence constituents 'limit' or 'describe' the form, the y are in construction with. That is why Bańczerowski, Pogonowski and Zgółka (1982: 271) while defining the term 'attribute' recall its syntactic function, pointing out the fact that it can be the determination of a subject, a (direct) object or another attribute. This particular question was also noticed and addressed by Podracki (1997: 101), later followed by Bąk (2004: 426), who emphasized that an attribute is every single description of a noun despite its function in a sentence. Podracki (1997: 103) also accentuates that apart from 'What? Which? How many? Whose?' etc. questions, the attribute gives answers to, and thus is perceived as a noun modifier, it can as well answer the same questions originally used to identify an object or an adverbial. The difference lays however, in the above-mentioned word class, to which the head belongs. ${ }^{15}$ That is why he proposed to enclose in the definition as a necessary prerequisite the fact, that it can also answer the questions originally answered by the object or the adverbial, that is e.g. 'How? or Where?'.

Szober (1924: 92) perceives attributes as a part of a subject or a complex predicate (Pol. orzeczenie rozwinięte), which indicating its property gives additional information about a noun, an adjective, a verb or an adverb. ${ }^{16}$

Klemensiewicz (1963: 56) starts his definition of attributes with the enumeration of word classes, which as heads can be modified by the $\mathrm{m}$, namely: noun, nominal pronoun (Pol. zaimek rzeczownikowy), nominal numeral (Pol. liczebnik rzeczownikowy), nominalized (or substantivized) adjective (Pol. urzeczownikowiony przymiotnik) and declinable participles (Pol. imiesłów odmienny), by which he means adjectival participles. He also notices that nouns are the most frequently used as heads and adds that thanks to the fact that attributes indicate certain properties of the head, it is easier

determinans, determinant, qualificator or the qualifying word are used to indicate the subordinate word.

${ }^{15}$ E.g. a) listening in silence - an attribute, b) The students were listening in silence. - an adverbial.

${ }^{16}$ According to traditional grammar among complex predicates are those built from e.g. a copula with a noun or an adjective. 
to distinguish the head (an object) from similar objects. ${ }^{17}$ The definition by Klemensiewicz was often referred to by other linguists and used in general definitions of this sentence component.

Polański (2003: 470-2) also refers to the syntactic function and semantic features of attributes, which is being the subordinate part of the sentence defined by the subsidiary relation (Pol. związek poboczny) with a noun as its superordinate. Semantic definition says that it indicates a property of an object; nevertheless as he explains, the term 'property' has a somewhat ambiguous meaning.

Nagórko (2005: 283) also refers to the subordinate nature of an attribute in a NP with a head noun, emphasizing at the same time the differences between its attributive relation with the superordinate and the predicative relations between the subject and the predicate (since it lacks the time characteristics) ${ }^{18}$. She also notices that in complex NPs one attribute can be subordinate towards another attribute, which was previously indicated by Bańczerowski, Pogonowski and Zgółka (1982: 271). She also convinces that syntactically analyzable NPs with attributes are, from the formal point of view similar to idiomatic expressions, as in 'biaty kruk' or 'gwiazda polarna' meaning 'a rare book' and a 'lodestar' respectively (cf. Nagórko 2005: 284). ${ }^{19}$

The above definitions presented in 2.1 and 2.2 sections of this paper confirm that scholars while defining the term attribute in Korean

\footnotetext{
${ }^{17}$ An attribute is a description in a relationship with a noun, rarely nominal pronoun, nominal, nominalized (or substantivized) adjective and declinable participles as its head (an object). Its basic function is the determination (pol. określanie) of that object. Most often it is a property, which characterizes the object as to its structure, appearance, essence, application, use, etc. and, which thanks to this specific property that particular object, can be distinguished from other similar ones. This type of attribute is called property attributes (Pol. przydawka właściwościowa), apart from which a complimentative, subjective, adverbial and predicative ones exist (cf. Klemensiewicz 1983:56).

${ }^{18}$ E. g. in 'nienormalne dziecko' (abnormal child) versus 'Dziecko jest nienormalne.' (The child is abnormal.) (Nagórko 2005: 284). The NP cannot be complemented by any of the adverbs of time, while the sentence can, as in 'To dziecko jest dziś jakieś nienormalne.' (This child is today somehow abnormal.)

${ }^{19}$ Interestingly enough not every research on attributes actually gives their definition. Frankowska (1982) can serve as an example here. Despite devoting her entire monograph to the subject of the obligatory determiner in NPs, not only she does not define the term but also she chooses to use the term 'dependent' (Pol. podrzędnik) instead.
} 
and Polish focus on its various properties. Nonetheless despite some definitional differences, in both languages it is unequivocally described as one of the secondary parts of a sentence (Kor. 부속성분, Pol. drugorzędna część zdania) - in Korean along with an adverbial, and in Polish with an adverbial and an object too.

\section{Various Approaches to the Classification of Attributes}

The attribute, as a part of a sentence, is generally distinguished and classified on the basis of its syntactic function and semantic properties. In the following sections their classifications in both languages will be looked into.

\subsection{Classifications of Attributes in Korean}

Korean linguists such as 김봉모 (1978: 18), 리의도 (1982), 김기복 (1999: 1), 남기심 and 고영근 (1985/2006) as well as many others, following the traditional grammar, despite using various terms, unanimously include to the category of attributes:

(i) the attributive forms of predicatives - verbs, adjectives as well as those formed from a substantive and a copula (purissi, purissihyeong, yongeonui gwanhyeongsahyeong, Kor. 풀이씨, 풀이씨형, 용언의 관형사형 respectively),

(ii) the substantives with or without the genitive case particle (imjassihyeong, cheeonui gwanhyeonghwa, Kor. 임자씨형, 체언의 관형화 respectively),

(iii) the determiners (maegimssi, maegimssihyeong, gwanhyeongsa, Kor. 매김씨, 매김씨형, 관형사 respectively).

However, apart from word classes enumerated above, there are also other language units (Kor. 언어 단위), which should be included into the category of attributes, since they can perform 
the same role in a sentence - namely phrases (e.g. noun or attributive phrases, myeongsagu, gwanhyeongsagu, Kor. 명사구, 관형사구 respectively) (cf. 한길 1997: 9) and attributive clauses (gwanhyeongjeol, Kor. 관형절) (cf. 김정숙 외 2005: 75, 한국방송통신대학교 평생교육원 2005: 137-8). ${ }^{2021}$

Among criteria used by Korean linguists to classify attributes are:

(i) word-class affiliation (e.g. 김기복 1999, 오규환 2016),

(ii) structure (e.g. 오규환 2016),

(iii) the type of function (e.g. 김봉모 1978, 리의도 1982).

김기복 (1999) divides attributes from formal point of view into:

(i) determinative attributes (gwanhyeongsa gwanhyeongeo, Kor. 관형사 관형어 $)^{22}$

- descriptive determiners (seongsang gwanhyeongsa, Kor. 성상 관형사)

- demonstrative determiners (jisi gwanhyeongsa, Kor. 지시 관형사)

${ }^{20}$ E.g. a) 날씨가 춥기 때문에- because of the cold weather (the nominal phrase),

b) 아주 헌 자전거 - a very old bicycle (the attributive phrase),

c) 마리아가 산 사과 - the apple(s) that Maria bought (the attributive/ adnominal clause).

21 한국방송통신대학교 평생교육원 (2005: 137-8) emphasize the necessity to distinguish attributive clauses (Kor. 관형절) from attributive phrases (Kor. 관형구) and point out that if only the attributive forms of predicatives are used they should be treated as phrases, however when the subject of the clause is elided as in 'a red flower' (Kor. 붉은 꽃) it should be treated as a clause, since 'red' in 'a red flower' comes from the sentence with the subject-predicate structure, namely 'The rose is red.' (Kor. 꽃이 붉다), that is why it can be perceived as a clause. Nevertheless in case of 'downright lie' (Kor. 새빨간 거짓말) since the structure 'The lie is downright.' (Kor. *거짓말이 새빨강다) does not exist, in other words it does not come from the subject-predicate structure it cannot become a clause. Yeon and Brown (2011: 5) and others call structures such as '마신 술' (Eng. drunk alcohol) as 'a modifying clause complementing the noun'.

22 김기복(1999: 125-6) in English abstract of his thesis actually uses the following terms: (i) determiners (state, quantitative and demonstrative ones), (ii) nominal attributives and (iii) verbal attributives. In this paper however (i) and (iii) will be referred to as 'determinative attributes' and 'predicative attributes' respectively. The reason is that the term 'determiner' is also used as a name for Korean part of speech and that the 'verbal attributives' also include adjectival ones, although the name does not imply it. 
- quantitative determiners (su gwanhyeongsa, Kor. 수 관형사)

(ii) substantive or nominal attributes (cheeon gwanhyeongeo, Kor. 체언 관형어)

- those, which can be used with or without the genitive particle,

- those, which cannot be used with the genitive particle,

(iii) predicative attributes (yongeon gwanhyeongeo, Kor. 용언 관형어)

- verbal participles (dongsaui gwanhyeongsahyeong, Kor. 동사의 관형사형),

- adjectival participles (hyeongyongsaui gwanhyeongsahyeong, Kor. 형용사의 관형사형). ${ }^{23}$

As far as the above classifications are concerned, although 김기복 among attributes of the first type enumerates three subclasses of the determiners (Kor.관형사), which are in fact word-class and not attributes, we could, following the classification proposed by 한국방송통신대학교 평생교육원 (2005: 139), name them respectively as:

(i) shape or state \{condition $\}$ attributes (moyangina sangtaereul natanaeneun gwanhyeongeo, Kor. 모양이나 상태를 나타내는 관형어),

(ii) demonstrative attributes (jisi gwanhyeongeo, Kor. 지시 관형어),

(iii) quantitative attributes (suryangeul natanaeneun gwanhyeongeo, Kor. 수량을 나타내는 관형어).

\footnotetext{
${ }^{23}$ There are also more general and thus less precise formal classifications of attributes. 임지룡 et al. (2005: 246) distinguish only two kinds of them, namely those expressed with determiners and those expressed with substantives (which can be used without the genitive case particle). 한국방송통신대학교 평생교육원 (2005: 139) mention only three kinds of attributes belonging to the class of determiners (namely those which indicate the location, number and shape or state, Kor. 지시 관형어, 수량을 나타내는 관형어 and 모양이나 상태를 나타내는 관형어 respectively).
} 
오규환 (2016: 197) focusing on complex attributes with free and bound nouns as their heads proposes the following classification:

(i) attributes related to substantives (cheeon gwallyeon gwanhyeongeo, Kor. 체언 관련 관형어)

- postpositional phrases with the genitive case particle (Kor. '-의' 조사구)

e.g. $\underline{\operatorname{tree}} \operatorname{root}\{\mathrm{s}\}$ (Kor. 나무의 뿌리)

- words with the genitive particle (' $X$-ui' hyeong daneo, Kor. 'X-의' 형 단어 $)^{24}$

e.g. the chance of a lifetime (일 생일 대의 기회), smile of satisfaction (Kor. 회심의 미소) ${ }^{25}$

(ii) attributes related to predicatives (yongeon gwallyeon gwanhyeongeo, Kor. 용언 관련 관형어)

- attributive forms of predicatives (yongeonui gwanhyeongsahyeong, Kor. 용언의 관형사형),

e.g. a beautiful flower (Kor. 예븐 꽃),

- predicatives of incomplete affiliation (yongeonui burwanjeon gyeyeolhyeong, Kor. 용언의 불완전 계열형 $)^{26}$,

e.g. very/ extremely long winter (Kor. 기나긴 겨울), generous love (Kor. 아낌없는 사랑),

- lexicalized determiners (eohwihwahan gwanhyeongsa, Kor. 어휘화한 관형사)

e.g. different place (Kor. 딴 데), old/ shabby clothes (Kor. 헌 옷).

오규환 (2016: 199) also notices, that the above-mentioned types of attributes form two kinds of structures with their heads, and thus can also be classified into:

\footnotetext{
${ }^{24}$ It is difficult to grasp the structural difference between the 'postpostional phrases' and 'words used with the genitive particle', proposed by 오규환. One could presume that it lies in the origin of the words to which the particle is attached, since given examples of the first kind are Korean native words (e.g. a tree), while those belonging to the second category Sino-Korean ones (cf. pp. 211-15).

25 오규환 (2016) however does not address the question of omission or the obligatory usage of the genitive case particle in the NPs with a nominal attribute.

${ }^{26}$ Although not explicitly explained, attributes included into this category are verb and adjectives' stems, which are the result of derivation or composition. This differs them form the first subclass, namely 'adnominal forms of predicatives'.
} 
(i) syntactic structures

(attributes which are the attributive forms of predicatives and those formed with the genitive case particle),

(ii) morphological structures ${ }^{27}$

(attributes which are lexicalized determiners and predicatives of 'incomplete affiliation').

김봉모(1978) and 리의도(1982) based their classification of attributes on functional criteria, namely, as the y explain on the way in which the attribute limits the meaning of the head, and distinguished those which have:

(i) the restrictive function (jehan $\{j e o k\}$ gineung or hanjeongjeok gineung, Kor. 제한 $\{$ 적\} 기능, 한정적 기능 respectively),

(ii) the non-restrictive function (bijehan\{jeok\} gineung or bihanjeongjeok gineung, Kor. 비제한\{적\} 기능, 비한정적 기능 respectively).

The first one by indicating some feature of the head narrows its semantic scope, as in 'red rose $\{\mathrm{s}\}$ ' (ppalgan jangmikkot, Kor. 빨간 장미꽃), where thanks to the attribute not all, but only red roses are referred to. The second type of attributes, on the other hand, gives additional or relevant information about the head, as in 'Warsaw, the capital of Poland' (pollandeu sudoin bareusyaba, Kor. 폴란드 수도인 바르샤바).

김기복 (1992: 2) indicates that the attributes with the restrictive function reveal characteristic or likely properties of the head. 리의도 (1982: 127-8) however, points out that the meaning expressed with these attributes is not universal or general and it can be either true or not. What is more, the relation between the head and its determinans does not have so-called 'sufficient correlation'

27 오규환 (2016: 215) mentions that some of the heads modified by attributes reveal some restrictions concerning their distribution, while the others have a high possibility of being perceived as one word, by which he means a compound. Some similarities between determiners and prefixes in respect to the headword (or root) convinced him to include them into the morphologically complex attributes (hyeongtaeronjeok bokhap gwanhyeongeo, Kor. 형태론적 복합 관형어). 
(chungbunhan sanggwanseong, Kor. 충분한 상관성), by which 리의도 means that, if something is e.g. brown it does not have to be e.g. a dog, and if we are talking about a dog, it does not have to be brown. That is why this kind of relation is referred to as arbitrary or temporary one (imui gwangye, ilsi gwangye, Kor. 임의 관계, 일시 관계 respectively).

Since the attributes with non-restrictive function indicate universal, well-known facts as well as general or inevitable facts (cf. 리의도 1982: 130-1, 김기복 1992: 2) and as such do not give any new information whatsoever, their usage is not obligatory. In other words, the sentence they might be used in conveys the complete information, which does not require any complementation. The head they modify is a unique or individual concept (dandokgaenyeom, Kor. 단독개념), while the relation between the head and its determinans following the terminology proposed by 리의도 can be called inevitable (piryeon gwangye, Kor. 필연 관계) or permanent (yeonggu gwangye, Kor. 영구 관계). Attributes with the non-restrictive function are exemplified below.

a) 1443 년에 한글을 만든 세종은 큰임금님이다.

1443nyeone hangeureul mandeun sejongeun
keunimgeumnimida

King Sejong, who created Hangeul in 1443, is a great king.

b) 거북선을 만든 이순신은 위대한 영웅이다.

geobukseoneul mandeun isunsineun widaehan yeongungida

Yi Sun-shin, who made a Turtle Ship, is a great hero.

In this context the restrictive attribute simply narrows the meaning of its head, while the non-restrictive one, since the meaning of the head is already limited, provides only some additional information. In other words if the relation between the head and an attribute is arbitrary or temporary one, the attribute is of restrictive type. However, if the relation is inevitable or permanent, than the attribute is of non-restrictive type.

Another feature concerning the usage of the non-restrictive attributes is the necessity to use a pause (swim, hyuji, Kor. 쉼, 휴지) between an attribute and its head. If there is no pause, the whole expression is often perceived (in a daily conversation) as somewhat unnatural or causing a confusion as to its meaning. Using the pause 
results placing the stress on the head, which is a natural and a common thing (cf. 리의도 1982: 139-140).

Nevertheless as 김봉모 (1978: 21) points out, both types of attributes are expressed with the same endings, despite the function the y have. ${ }^{28}$ 리의도 (1982: 138-9) goes even further by saying that having the same structure of the sentence, it is the perception of the relation between the head and its determinans, which influences the speaker's decision concerning the nature of the attribute. This means that if he or she would consider it to be an arbitrary one the attribute would have the restrictive function, otherwise the notrestrictive one as in e.g. a hard-working Chinese (bujireonhan junggugin, Kor. 부지런한 중국인).

\subsection{Classifications of Attributes in Polish}

Since the primary function of an adjective in a sentence in Polish language is modifying the head as an attribute, it is not a surprise that it is the adjectives, which are usually mentioned as first, when referring to word classes, which can become attributes in a sentence. Nevertheless this function can also be performed other various word classes or linguistic units, all of which are listed below.

(i) adjectives,

(ii) adjectival pronouns (possessive, demonstrative, indefinite, negative pronouns etc.),

(iii) adjectival participles (active and passive adjectival participles),

(iv) numerals (cardinal, ordinal, multiplicative, main-fold numerals, etc.),

(v) nouns (in the nominative and dative case),

(vi) prepositional phrases,

28 김봉모 (1978: 32) also explains when the attribute has one of the referred functions. Namely, if the head is a common noun, a proper noun used as a common noun or a numeral. The non-restrictive function have the attributes, which describe a proper noun being a unique referent (yuil jisimul, Kor. 유일 지시물) or a pronoun. He also argues that determiners have only the restrictive function. 
(vii) infinitives, ${ }^{29}$

(viii) attributive (subordinate) clauses (Pol. zdanie podrzędne przydawkowe $)^{30}$.

Although various classifications of attributes in Polish language do exist, they are usually based on one or more than one of the following criteria nevertheless the most widely used ones are those based on more than one of the m (e.g. formal and semantic properties):

(i) semantic properties,

(ii) formal properties (morphologically inflected type),

(iii) syntactic properties (the type of syntactic relation with the head).

As far as the semantic classification is concerned GębkaWolak (2000), Jadacka (2005) and Nagórko (2005), propose to divide attributes into:

(i) qualitative attributes (Pol. przydawka jakościowa),

(ii) classificatory attributes (Pol. przydawka klasyfikująca) ${ }^{31}$.

Qualitative attributes 'characterize the noun from the point of view of its quality or characteristic' (Zagorska-Brooks 1975: 382), the y indicate regular or common features (Nagórko 2005: 285) or describe somewhat random properties, which indicate regular

\footnotetext{
${ }^{29}$ Very few linguists actually mention the usage of infinitives as attributes; among them are Klemensiewicz (1963: 58) and Bańczerowski, Pogonowski and Zgółka (1982: 271).

${ }^{30}$ Klemensiewicz (1986: 138) divides attributive (subordinate) clauses into three following types:

(i) The relative clauses (Pol. zdania względne) e. g. Zły to ptak, co własne gniazdo kala. (It's an ill bird that fouls its own nest.)

(ii) The conjunctive clauses (Pol. zdania spójnikowe) e. g. Czyny Twoje nie są takie, abyś sie $\mathrm{z}$ nimi musiał ukrywać. (Your actions are not $\{$ that bad so $\}$ that you would have to hide doing them.)

(iii) The asyndetic clauses (Pol. zdania bezspójnikowe) e. g. Dokoła były sarnie $\mathrm{i}$ jelenie rogi $\mathrm{z}$ napisami gdzie, kiedy te hupy zdobyto. (There were roe and deer horns, with inscriptions where, $\{$ and $\}$ when those booties were obtained.)

${ }^{31}$ Although there are two terms used to indicate 'przydawka klasyfikująca' in Polish namely classificatory (cf. Linde-Usiekniewicz 2013) and classifying (cf. Cetnarowska 2013) in this paper the former one will be used.
} 
quality (cf. Jadacka 2005: 169-170) of the head, such as 'good, delicious, interesting, extraordinary, valuable' etc., and as such precede the head noun. Classificatory attributes, on the contrary, form the elements of closed terminological or classification systems, and as such are placed after the superordinate word. ${ }^{32}$ Their both types are exemplified below.

a) niezwykta literatura ('exceptional literature')

b) literatura piękna (Belles-lettres)

Curiously enough the same attribute, depending on its prepositional or postpositional order in regards to the head, can in one NP become a qualitative one and in another a classificatory one, which is shown in the below Ex. 3. It is also worth to mention that the reversed word order differentiates loose syntagms (Pol. luźne syntagmy) from undivided phrases used as proper names. ${ }^{33}$ NPs exemplified below appear in the following order - syntactic groups versus proper names. In this context Gębka-Wolak (2000: 24) and Jadacka (2005: 171) point out that adjectives in noun-adjective phrases have 'meaning-creative function', which was also taken up by Nagórko (2005: 261), who convinces that the meaning of NPs depends on the location of the attribute and in this context she refers to two just mentioned types.
a) śpiewający ptak (a singing bird) versus ptak śpiewajacy (a songbird),
b) kulturalny attaché (well-mannered attaché) versus attaché kulturalny (a cultural attaché),

\footnotetext{
32 The criterion of gradation can also help to distinguish these two types of attributes, since only the qualitative ones can actually form degrees of comparison and in fact have lexical antonyms (e.g. good-bad versus Japanese - ?) (cf. Jadacka 2005: 170).

${ }^{33}$ Willim (2000: 37-70) analyzing the relation between the head and the adjective points out that some NPs can be separated while the others cannot. She calls them juxtaposition (Pol. zestawienie) and free or unrestricted combination (Pol. swobodne połączenie) respectively. Rutkowski et al. (2005: 2) along with just cited Willim (2000:41) notice that the first kind of adjectives cannot be coordinated with other adjectives and they tend not to have the predicative function, they neither have the gradation nor a $\{$ lexical $\}$ antonym, since they refer to entity and not properties.
} 
Despite the differences in the function of attributes in just cited noun phrases and their position in regard to the head, the rules 'the qualitative attribute + the head' and 'the head + the classificatory attribute' are not always strictly followed. Jadacka (2005: 170) exemplifies their reversed word order with medical terms such as 'cesarskie cięcie' (Caesarean section), 'kurza ślepota' (moon blindness) and idiomatic expressions, with denominal adjectives of historical and mythological genesis, derived from proper nouns such as 'syzyfowa praca' (Sisyphean labours) or 'bajońskie sumy' (king's ransom), which came from Sisyphus and the Bayonne, meaning and the king of Ephyra and a French city respectively.

It is also worth to mention, that both topic-comment structure as well as the context, determine the sequence of words in a sentence. ${ }^{34}$ However, if the context does not change the word order, the classical order is recommendable - namely the subject (with attribute(s)), predicate and complement(s). ${ }^{35}$

Although several classifications of attributes from the formal point of view do exist (e.g. Klemensiewicz $1986^{36}$, Podracki $1997^{37}$,

\footnotetext{
${ }^{34}$ Although Gębka-Wolak (2000: 32) convinces that they do not determine but only modify it.

${ }^{35}$ Weinsberg (1983: 189-94) however proposes different classification of Polish attributes based on their meaning. Although he distinguishes three kinds of them, namely: genitive (Pol. dopełniaczowe), possessive (Pol. dzierżawcze) and specifying (Pol. wyznaczające) ones. The first two are in fact discussed together and subdivided into 4 subcategories according to the properties of the head noun, described by an attribute into, those which are: (i) a concrete non-relational noun, (ii) a concrete relational noun, (iii) those, which are the name of an activity or a feature or (iv) the name of the unit of measurement. The specifying attributes (Pol. przydawki wyznaczające) are defined as those, which characterize the very unique property of the head (e.g. 'the world's only talking dolphin').

36 Klemensiewicz (1986: 128-31) uses the term 'proper attribute', to which he includes quality attributes, nominal attributes (expressed in the nominative case), genitive attributes and prepositional ones. Outside of this category are adverbial, objective and subjective attributes.

${ }^{37}$ Podracki (1997: 105) divides the attributes in a similar way to Klemensiewicz (1986), however he does not include genitive and prepositional attributes into nominal ones instead. He proposes a subclass of 'formally peculiar attributes' (Pol. przydawki formalnie osobliwe), some of them Nagórko (2005) includes into the category of nominal attributes (those expressing comparative constructions). Nevertheless Podracki to the category of formally peculiar attributes includes also attributes expressed e.g. with an infinitive (e.g. czas pracować - time to work). Klemensiewicz (1963: 57) to the category of 'formally peculiar attributes' includes however not only
} 
Bąk $2004^{38}$ etc.), the one proposed by Nagórko (2005: 285-88) in author's opinion, appears to be the most transparent one. It is based on the morphological and inflectional type (Pol. typ morfologicznofleksyjny), according to which she distinguishes:

(i) adjectival attributes (Pol. przydawki przymiotne)

- the subordinate word being in concord with the head takes the same case, number and gender as the superordinate word $)^{39}$ e.g. pierwsze przymrozki/ the first frost; okoliczni mieszkańcy/ local residents; te łzy/ these tears ${ }^{40}$;

(ii) nominal attributes (Pol. przydawki rzeczowne)

- they are expressed by subordinate nouns and can be classified according to the inflectional form of the noun into three following types (cf. Nagórko 2005: 285-6):

a) nominative attributes (Pol. przydawki mianownikowe) - the y stay in concord with the superordinate noun or are combined with the head through comparative conjunction, such as 'jak' meaning 'like'. e.g. nos jak kartofell a nose like a potato;

b) genitive attributes (Pol. przydawki dopełniaczowe) are the most common type, e.g. kostka mastal a stick

those expressed with infinitives, but also with comparative constructions, adverbs and clauses.

${ }^{38}$ The classification by Bąk (2004: 426-430) partially overlaps with the one proposed by Podracki (1997: 105) since he also mentions adjectival, nominal and prepositional attributes, nevertheless he does not distinguish the category of 'formally peculiar attributes', but instead he adds: (i) adverbial attributes (Pol. przydawki okolicznikowe); and (ii) appositional attributes (Pol. przydawki dopowiadające or dopowiedzenia).

39 Although the relation in traditional grammar is called the 'agreement' Nagórko (2005:284) uses the term 'accommodation'.

40 Bąk (2004: 426-7) following Klemensiewicz (1963: 56-63) subdivides the adjectival attributes according to their word-classes into: adjective, participial, pronominal and numeral attributes. The first two kinds answer the 'What?' question, while pronominal and numeral ones (expressed by ordinal numbers) answer the 'Which?' and 'Whose?' questions and those expressed by cardinal numbers give the answer to 'How many?' question. 
of butter; dom kolegil friend's house. Semantic relations between the two nouns are of various types and thus it is difficult to enumerate all of them, however, the subordinate nouns usually characterize the property, affiliation or the quantity, as in e.g. liść klonul a maple leaf, litr mleka/ liter of milk. ${ }^{41}$

c) attributes expressed with a preposition - they are placed after the word being described and their case depends on the preposition, e.g. kawa bez cukru[GEN] (coffee without sugar), odpoczynek na powietrzu [DAT] (relaxation in the open air);

(iii) appositions (Pol. dopowiedzenia) the y are a special type of postposition and are expressed with nominal attribute always placed after the noun or nominal pronoun and can be also used with other attributes. They are typical to rhetoric styles and frequently used in romantic poetry (cf. Nagórko 2005: 287).

e.g. Patrzę w niebo, gwiazd szukam, przewodniczek łodzi.

I'm looking at the sky, searching for stars, boats' pointers.

(iv) predicative attributes (Pol. przydawki predykatywne/ orzekające) - this type of attributes not only semantically connects with the superordinate word (e.g. noun), but also with the predicate. Their grammatical categories are however influenced by the subject of the sentence and its categories, e. g. Zosia obudziła się chora./ Sophie woke up sick (cf. Nagórko 2005: 288).

Urbańczyk (1999: 304) on the other hand, as a primary criterion for classification of attributes uses the type of syntactic relation with a head noun - that is a concord (also called agreement

\footnotetext{
${ }^{41}$ Nagórko (2005: 287) also points out that complements in the genitive when nominalized are replaced by the genitive attributes, as in e.g. budować $d o m /$ to build a house $\rightarrow$ budowa domu/ the building of a house.
} 
or parataxis) ${ }^{42}$ or a regimen (also referred to as government, rection or hypotaxis) ${ }^{43}$. Another dimension taken into account is the inflectional type.

(i) attributes bonded with the head noun in a concord:

a) adjectival attributes (Pol. przydawki przymiotne),

b) pronominal attributes (Pol. przydawki zaimkowe),

c) numeral attributes (Pol. przydawki liczebnikowe),

d) participial attributes (Pol. przydawki imiesłowowe),

(ii) attributes bonded with the head noun in a regimen ${ }^{44}$ :

a) genitive attributes (Pol. przydawki dopełniaczowe).

Polański (2003: 471-2) following Klemensiewicz (1963: 5665 and 1986: 128-31) gives the classification of attributes used in Polish grammatical tradition. It reveals that apart from the semantic dimension, the syntactic one was also used here:

(i) property attributes (Pol. przydawki właściwościowe) they are the most important ones and can be further subdivided according to the semantic features they have into:

a) characterizing attributes (Pol. przydawki charakteryzujące)

e.g. ubogi człowiek/a poor man; drewniany most/ a wooden bridge,

b) affiliating attributes (Pol. przydawki przynależnościowe)

\footnotetext{
42 'Agreement' is a requirement of the superordinate towards the subordinate word and it usually involves making the value of some grammatical category such as gender or person "agree" between the words in a phrase or parts of the sentence.

43 Here the government refers to 'the case government' (the government of the grammatical case of verb arguments, when a verb or preposition is said to 'govern' the grammatical case or its noun phrase complement) - meaning that the subordinate word has to take a particular case required by the superordinate word, as in 'widzę psa' [GEN] (I see a dog.) or 'wierny przyjacielowi' [DAT] (faithful to $a$ friend).

44 They characterize the property of the head, show its affiliation or indicate the quantity (cf. Urbańczyk 1999: 304).
} 
e.g. łódź rybackal a fishing boat; moje dziecko/ my child,

c) individualizing/ distinctive attributes (Pol. przydawki wyodrębniające)

e.g. ten dom/ this house; każy obywatel/ every citizen,

d) quantitative attributes (Pol. przydawki ilościowe) e.g. pierwszy prezydent/ the first president; $d w o ́ c h$ posłów/ two deputies ${ }^{45}$

(ii) complimentative attributes (Pol. przydawki dopełnieniowe)

e.g. pamięć $o$ zmartych/ the memory of the deceased; budowa mostu/ construction of a bridge,

(iii) subjective attributes (Pol. przydawki podmiotowe) e.g. atak lotnictwal air force attack; wściekłość wrogal the rage of the enemy,

(iv) adverbial attributes (Pol. przydawki okolicznościowe) ${ }^{46}$

e.g. podróż nocą/journey by [at] night; dom nad jeziorem/ a house by the lake,

(v) predicative attributes (Pol. przydawki orzekające) ${ }^{47}$ e.g. Chory na tyfus, Piotr leży w szpitalu./ Ill with typhus Peter is in a hospital.

It is also worth to mention some terminological differences concerning attributes. Bąk (2004) while referring to attributes expressed with the genitive case as in 'brat ojca' meaning 'father's brother', does not call them genitive attributes (Pol. przydawki dopełniaczowe) as e.g. Klemensiewicz (1986), Podracki (1997),

\footnotetext{
${ }^{45}$ Formally property attributes (Pol. przydawki właściwościowe) are divided into the adjectival attributes (Pol. przydawki przymiotne) and the nominal attributes (Pol. przydawki rzeczowne) (cf. Polański 2003: 472). The first one creates a concord with the head as, in e.g. 'dobry człowiek/ a good person', while the second one creates regimen as in e.g. minister finansów/ the finance minister [the minister of finance]' or the relation of belonging (zwiazek przynależności) as in 'mężczyzna $z$ brodąl a man with a beard'.

${ }^{46}$ Despite the fact that they do correspond to adverbials they are not in fact called 'adverbial attributes' (Pol. przydawki okolicznikowe) but 'circumstances indicating attributes' (Pol. przydawki okolicznościowe) in Polish (cf. also Gołąb et al. 1968: 467). Nonetheless for the transparency reasons the Author decided to translate them as adverbial ones.

${ }^{47}$ Predicative attributes combine the function of an attribute and a predicate. They are written with commas and are in apposition (cf. Polański 2003: 471-2).
} 
Urbańczyk (1999) and Nagórko (2005) do, but refers to them as complimentative attributes (Pol. przydawki dopełnieniowe) or complementary attributes (Pol. przydawki dopełniające). Bąk (2004) explains, that the $y$ differ from quality, nominal and prepositional attributes, since they do not indicate the color, size or amount etc. but the y supplement the meaning in the same way as complements do. He also explains that this is the reason why they are used only with deverbal or deadjectival nouns, which take complements as in 'pisanie zadania' meaning 'homework writing' (from 'piszę zadanie'/ I am writing [my] homework) or 'budowa domu' meaning 'house building/ building of a house' (from 'buduję dom'/ 'I am building a house') (cf. Bąk 2004: 428-9). Klemensiewicz (1986: 130-1) on the other hand perceives the genitive attribute (Pol. przydawka dopełniaczowa) and the complementary one (Pol. przydawka dopełniająca) as two different types of attributes, so do Gołąb et al. (1968: 476).

\section{Parameters for Classification of Attributes in Korean and Polish}

As shown in the above sections 2 and 3 - both Korean and Polish linguists apart from defining what the attribute is introduced several classifications based on various criteria. Consequently, taking into consideration morphological, semantic and syntactic properties that attributes in both languages possess, we can propose the classification based on a set of parameters, which reflect the m.

Since the classification, as Szulc (1984: 110) points out, means grouping elements, which stay in the paradigmatic relation with one another, within one class of elements, the classification understood as a set of items (or properties) $\chi$, should satisfy few conditions, defined by Mostowski (1948: 137) and recalled by Wójcik (1965: 14, 35). They are as follows:

(i) every element of the set $\mathrm{X}$ has at least one of the properties belonging to $\chi$,

(ii) if properties $\mathrm{Y}$ and $\mathrm{Z}$ belong to $\chi$, the $\mathrm{y}$ are equal or separable. 
This means that the classification is a set of sets, understood a set of properties of objects, which meet certain conditions. Good classification should fulfill formal conditions - that is being comprehensive and separable (Pol. wyczerpująca i rozłączna) (cf. Kotarbiński 1963: 41 after Wójcik 1965: 16-7). ${ }^{48}$ The first criterion is satisfied, when the sum of the partial ranges (Pol. zakres cząstkowy) equals with the entire range (Pol. cały zakres). The second one means, that none of the elements of the range can belong to two different partial ranges, on which the entire range is divided. Bańczerowski, Pogonowski and Zgółka (1982) also add that none of the subsets in a set can be empty, which means that it has to have at least one element.

Bearing in mind those indispensable conditions, the Author would like to propose a set of parameters, which could not only help to characterize attributes in Korean and Polish in a more comprehensive way, but also thanks to which their classification in both languages would be more transparent. Consequently, the attributes in question can be divided according to formal, semantic and syntactic parameters, as follows:

(i) formal parameters:

a) membership in partes orationis (nouns, pronouns etc.),

b) the type of language unit the y represent (words, phrases etc.),

c) inflection, namely the presence or absence of morphological markers (declinable versus indeclinable attributes),

d) structural complexity (simple versus complex attributes),

(ii) syntactic parameters:

a) the syntactic category of the head being described,

\footnotetext{
48 Also Ajdukiewicz (1965: 48) while explaining the essence of logical division refers to two conditions - namely the separability and the adequacy (Pol. warunek rozłączności i adekwatności). Their meaning overleaps with the conditions mentioned by Kotarbiński (1963).
} 
b) linear position with regard to the head (prepositional versus postpositional order),

c) the type of the syntactic relation with the head (concord versus regimen),

d) the type of syntactic relation with another attribute if used,

(iii) semantic parameters:

a) the degree of obligatoriness (obligatory versus nonobligatory attributes),

b) attribute sequentialization ${ }^{49}$.

Table 1. The parameters of attributes in Korean and Polish

\begin{tabular}{|c|c|c|c|c|c|c|}
\hline \multicolumn{5}{|c|}{ Parameters } & \multirow{2}{*}{$\begin{array}{c}\text { KR } \\
+ \\
\end{array}$} & \multirow{2}{*}{$\begin{array}{c}\text { PL } \\
+ \\
\end{array}$} \\
\hline \multirow{14}{*}{$\begin{array}{c}\mathbf{F} \\
\mathbf{O} \\
\mathbf{R} \\
\mathbf{M} \\
\mathbf{A} \\
\mathbf{L}\end{array}$} & \multirow{10}{*}{$\begin{array}{c}\text { Formal } \\
\text { representation } \\
\text { of attributes }\end{array}$} & \multirow{7}{*}{$\begin{array}{l}\mathrm{W} \\
\mathrm{o} \\
\mathrm{r} \\
\mathrm{d} \\
\mathrm{s}\end{array}$} & \multicolumn{2}{|r|}{ Nouns } & & \\
\hline & & & \multicolumn{2}{|c|}{ Pronouns } & + & + \\
\hline & & & \multicolumn{2}{|c|}{$\begin{array}{c}\text { Adjectives } \\
\text { (Participles) })^{50}\end{array}$} & + & + \\
\hline & & & \multirow{2}{*}{ Verb } & Participles $^{51}$ & + & + \\
\hline & & & & Infinitives & - & + \\
\hline & & & \multicolumn{2}{|c|}{ Determiners } & + & - \\
\hline & & & \multicolumn{2}{|c|}{ Numerals } & + & + \\
\hline & & \multirow{2}{*}{$\begin{array}{l}\text { Phra- } \\
\text { ses }\end{array}$} & & NPs & + & + \\
\hline & & & & PPs & - & + \\
\hline & & $\begin{array}{c}\text { Clau- } \\
\text { seas }\end{array}$ & & tive clauses & + & + \\
\hline & \multirow{2}{*}{ Flection } & \multicolumn{3}{|c|}{ Cases } & $+/-$ & $+/-$ \\
\hline & & \multicolumn{3}{|c|}{ Endings } & + & + \\
\hline & \multirow{2}{*}{$\begin{array}{c}\text { Structure } \\
\text { complexity }\end{array}$} & \multicolumn{3}{|c|}{ Simple attributes } & + & + \\
\hline & & \multicolumn{3}{|c|}{ Complex attributes } & + & + \\
\hline
\end{tabular}

${ }^{49}$ In both languages there are attributes, which despite their formal differences, convey the meaning of e.g. shape, size, color, material, temperature, age, origin etc. However, the question of meaning based sequentialization of them is a very complex issue, which requires in-depth analysis. That is why this particular parameter will not be discussed here.

${ }^{50}$ They can also be called 'adjectival participles'.

${ }^{51}$ They can also be referred to as 'verbal participles'. 
Anna BOROWIAK: A Draft Classification of Attributes ...

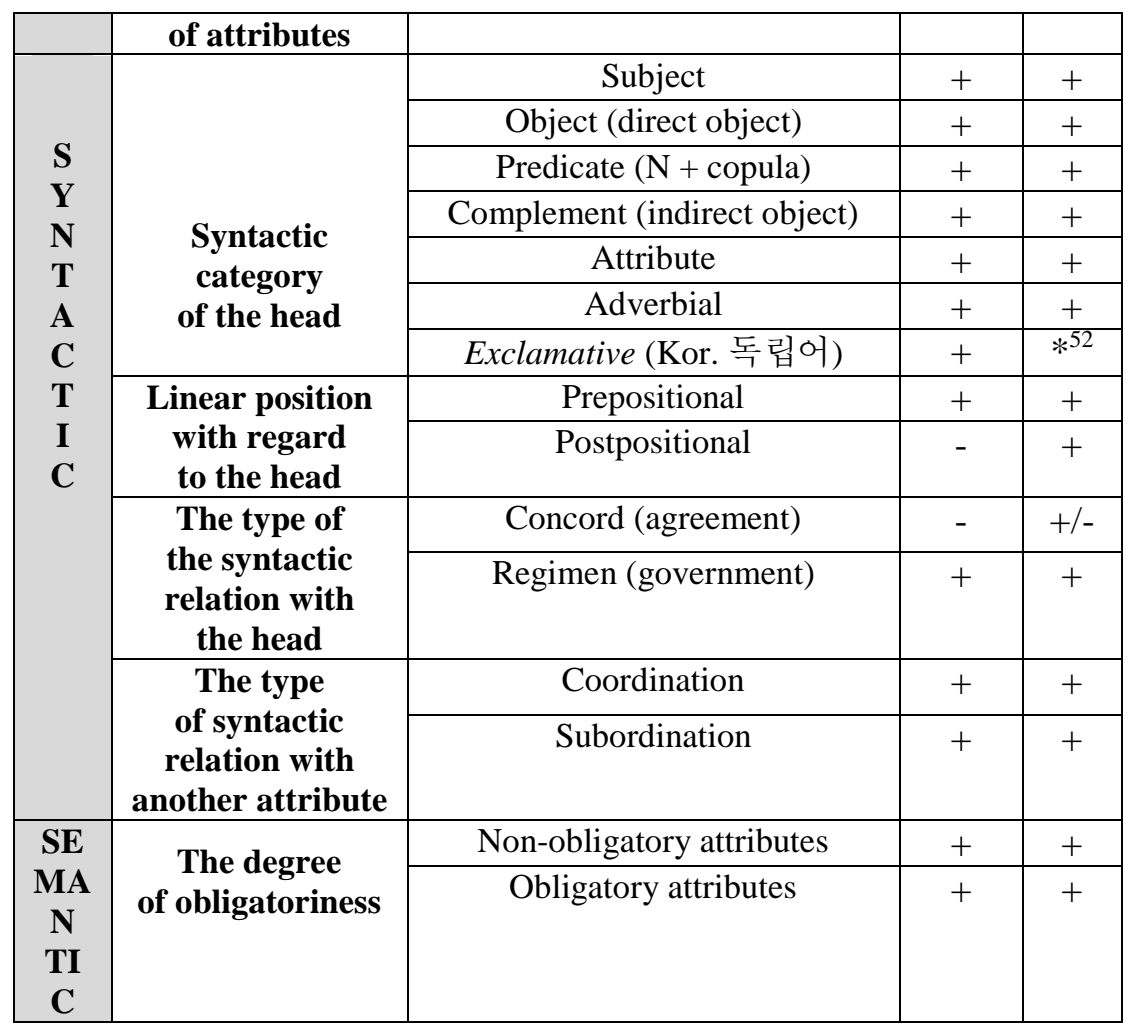

Despite the typological differences between Korean and Polish language, as regards to the existence of attributes and their properties, there are a lot of similarities, which the above <Table 1> shows. As far as the formal parameters are concerned, in both languages words as well as phrases and clauses can modify the head. Among words, which can be used attributively in both languages are: nouns, pronouns and numerals. Although the primary function of adjectives in Polish is to restrict the meaning of the superordinate

\footnotetext{
${ }^{52}$ Polish traditional grammar does not distinguish exclamative as a separate syntactic class. Nevertheless expressions, which function in Korean as dongnibeo (Kor. 독립어), can also be found in Polish. Klemensiewicz (1986: 132) refers to them as 'words being outside of the syntactic relations in a sentence', pointing out that they can neither become a modifier nor be modified, and exemplifies it with e.g. 'Do licha!' meaning 'Damn!', 'What on earth!' etc. However, 'Do licha jasnego!' or 'Do jasnego licha!' with reversed order confirm that at least some of them can be modified by attributes. Moreover, some of those expressions in fact contain attributes and will not be used without them as e.g. 'Do jasnej ciasnej!'
} 
word as modifier (despite requiring case, number and gender change) it is in Korean, where the adjectives undergo bigger transformation. It is because their primary function is not the attributive but the predicative one. That is why next to adjectives the participles were also distinguished. Although in both languages verbs can function as attributes only in Polish, apart from participles, infinitives can also be used. Since Polish has no separately distinguished word class of 'determiners' (gwanhyeongsa, Kor. 관형사) only in Korean they can modify the head as attributes.

In both languages apart from already mentioned words, the meaning of the head can also be modified by phrases (syntagmas) and clauses (relative clauses). While noun phrases are used in Korean and Polish, only in the latter the prepositional phrases can perform the attributive function. That is because Korean language has no prepositions and thus prepositional phased do not exist.

As far as the morphological markers (inflection) revealing the attributive function of the above mentioned units in Korean are concerned, attributes can be divided into two groups - those which do have and those, which do not have any markers whatsoever. The first group of attributes is composed of units, which take different markers, whose kind depends on the word class, to which the word performing the attributive function belongs. In other words, whether it inflects or not, and consequently e.g. nouns and pronouns, as indeclinable words ${ }^{53}$, will take the genitive case particle (-eui, Kor. -의 ${ }^{54}$, while declinable words such as adjectives and verbs will take

${ }^{53}$ According to Korean linguists (cf. 남기심 and 고영근 2006: 65 and many others) only verbs and adjectives are declinable words (gabyeoneo, Kor. 가변어), which means that the rest of word classes, including those taking particles (josa, Kor. 조사) - nouns, pronouns and numerals, are considered indeclinable words (bulbyeoneo, Kor. 불변어) since they do not take endings (eomi, Kor. 어미).

${ }^{54}$ According to 남기심 and 고영근 (2006: 269) and한길(1997: 9) the criteria when it is alright to omit the particle are not exactly known. Nevertheless 김정숙 et al. (2005: 823) notice that when the relation between two nouns indicate 'whole-part relationship' it can be omitted, however if it is used as a metaphor it cannot. The 'whole-part relationship' can however refer to: family or relative relationship, 'the possessor-possession' kind of relation or literal 'whole-part relationship' (cf. 안연령 2011). On the other hand, the omission of the genitive particle apart from the metaphoric usage, is also impossible in phrases with a classifier (phrases with order: du janui keopi (Kor. 두 잔의 커피, two cups of coffee) or when between the N+GEN and $\mathrm{N}$ another attribute is placed, as in seourui nun oneun geori (Kor. 서울의 눈 오는 거리, Seoul's snowy streets). 
attributive endings or connective endings (coordinate sentence endings), whose form not only depends on their word class affiliation but also varies according the category of time, honorification etc. as in 'the present for $\{\mathrm{my}\}$ great grandmother' (jeungjohalmeonikke deuril seonmul, Kor. 증조할머니께 드릴 선물) shows. Both types of endings are exemplified in the below (4.1) and (4.2).

(4.1) Attributive endings

a) -teon, Kor. - 던 (the retrospective modifying form),

b) -neun, Kor. -는 (the present tense modifying form used only with verbs),

c) -n, -(eu)n, Kor. -ㄴ/ -(으)ㄴ - the past tense, state/ result modifying form (attached to verbal and adjectival stems),

d) -(eu)l, Kor. -(으)르 the future/ prospective modifying form (as the previous one, it is used with both verbs and adjectives)

(4.2) Connective endings (coordinate sentence endings)

a) - go (Kor. -고),

b) -(eu)myeo (Kor. -(으)며),

c) -(eu)myeonseo (Kor. -(으)면서)

Verbs in Polish language also conjugate, which means that the usage of proper endings, which would allow them to perform the attributive function, is mandatory. Nevertheless apart from the category of time, the y also signify e.g. the number and gender, as in 'ptonacy statek' nom, Masc, sg (a burning ship).

In both languages however there are words, which despite having no attributive markers whatsoever do function as attributes. In Korean language it concerns the determiners (e.g. sae, Kor. 새, meaning 'new') or co-called gwanhyeongmyeongsa (Kor. 관형명사) words, which are formally nouns, but function as determiners (gwanhyeongsa, Kor. 관형사). In vast majority they are of Chinese origin and describe the following noun in the NP, however they can appear only as the first noun in the NP and can be used only as attributes. ${ }^{55}$ Despite the fact that Polish is inflectional language

55 김선효 (2002: 66-68) explains that this type of nouns neither can take any particles nor be described by other attributes, as in e.g. eotteon gukje (Kor. *어떤 국제), meotjin gukje (Kor. *멋진 국제). Some of them can however derive free nouns with 
and that adjectives are inflected words, not every adjective used as an attribute will have morphological markers reflecting the categories of the head. This concerns adjectives of foreign origin such as 'khaki'. The form of this adjectival attribute stays the same, regardless of the inherent gender the head, its number or case.

The structural complexity of attributes can be understood in two aspects - namely morphological one (meaning simple, derivative or compound attributes) or in respect to their formal representation (words, phrases etc.). Although in both languages simplex and complex words do function as attributes, in this research only the second aspect is being referred to. The attributive function in both languages can be performed either by single words functioning as simple attributes e.g. determiners (as in heon jajeongeo, Kor. 헌 자전거, old bike) in Korean, or nouns in both languages. Korean namu\{ui\} uija (Kor. 나무\{의\} 의자, a wooden chair) and Polish 'wściekłość wroga' meaning 'the rage of the enemy' can serve as examples here. In both languages, apart from single words and phrases clauses can also function as attributes. They however create complex attributes and can be exemplified with for example nega eoje bon yeonghwa (Kor. 네가 어제 본 영화; the movie you saw yesterday; film, który wczoraj widziateś).

As far as the syntactic parameters are concerned, attributes' properties in both languages can be classified according to the syntactic function of the head the y modify. Curiously enough, it turns out that an attribute can generally describe every part of the sentence, as long as it is performed by substantives, which also concerns predicates composed of a noun and a copula.

There are some differences however in regards to the linear position of attribute towards the head. While in Korean every attribute despite its structure, meaning and length appears in preposition, in Polish these three parameters decide, whether an attribute precedes or follows the head. Consequently, the prepositional word orders have: qualitative attributes (Pol. przydawki jakościowe), pronominal attributes (Pol. przydawki zaimkowe) and participial attributes (Pol. przydawki imiesłowowe), while postpositional one: classificatory attributes (Pol. przydawki klasyfikujące), nominal attributes (Pol.

suffixes such as - $h w a$ (Kor. -화) or -seong (Kor. - 성) or verbs, when joined with hada (Kor. - 하다). 
przydawki rzeczowne), adverbial attributes (Pol. przydawki okolicznościowe ${ }^{56}$ ) along with those composed of prepositional phrases (Pol. przydawka przyimkowa). It is worth to mention that the longer the attribute is, the stronger tendency to place it after the word being modified. It is done so in order to make easier to grasp the meaning of the whole phrase or sentence. Nevertheless also noteworthy is the fact that the same adjective can be used as pre-head and post-head modification - the first one exhibits the modifying function, while the second one the classificatory one, when combined with the head. This means that when used postpositionally it usually indicates of what kind the superordinate word is, as in e.g. szkoła podstawowa (a primary school) - meaning a type of school.

As far as the types of syntactic relations between or among attributes in both languages are concerned, both coordination and subordination can be observed. The first one however, is much more frequently observed and it suggests that attributes can change their order although with some semantic change e.g. ttokttokago jalsaenggin namja (Kor. 똑똑하고 잘생긴 남자; Eng. an intelligent and handsome man, Pol. inteligentny i przystojny mężczyzna). Nonetheless, modifying one attribute by another one ${ }^{57}$ creates the subordinate relation. Here the change of attributes' order if impossible influences the meaning, as in e.g. nae chinguui yeodongsaengeun chigwauisayeyo (Kor. 내 친구의 여동생은 치과의사예요. Eng. My friend's younger sister is a dentist. / Pol. Młodsza siostra mojego kolegi jest stomatologiem.). While in Polish the following change in the order of attributes is possible e.g. Młodsza siostra kolegi mojego jest stomatologiem. (Eng. \{literal translation \} A younger sister of a friend of mine is a dentist.) in the Korean it is not.

While discussing the properties of attributes, the question of their obligatoriness also has to be addressed here. Both Korean and Polish linguists agree that although attribute is generally not an obligatory part of the sentence and their omission does not

56 The term 'adverbial attribute' (Pol. 'przydawka okolicznościowa' and not 'przydawka okolicznikowa') was used e.g. by Klemensiewicz (1963: 64, 1986: 131), Polański et al. (2003: 471) etc. and it is defined as attribute which answers the same questions as adverbial modifying the predicate does. This kind of attributes has a deverbal or deadjectival noun, simple noun etc. as its head and answers the same questions concerning the place, time, manner etc. as an adverbial does (cf. Klemensiewicz 1963: 64).

57 An attribute can modify the subject, the object or another attribute (cf. Bańczerowski et al. 1982: 271). 
influence the grammatical correctness of the sentence, in some cases they have to be used. In Korean it concerns the situation when the bound nouns are used as heads, and in Polish when common nouns such as hands, hair, eyes etc. are used. Although in both cases it is explained that semantic reasons stand behind the obligatory usage of attributes, curiously enough in Korean it generally concerns synsemantic nouns such as geot (Kor. 것, 'thing'), te (Kor. 데, 'place, spot'), jeok (Kor. 적, 'the time \{when\}, an experience'), su (Kor. 수, 'a way; possibility, likelihood'), while in Polish the autosemantic ones, as already cited e.g. parts of the body. This means that it is the attribute that bears the informative load by defining the feature of the head noun and, as such, if omitted not only the noun would be deprived of its description, but also the phrase would become incomplete (e.g. *dziewczyna o oczach/ *a girl with eyes). Grzegorczykowa (1998: 24) calls the groups with obligatory determiner (Pol. grupy $\mathrm{z}$ determinatorem koniecznym) 'the special type of groups' and explains that the necessity to use the attribute (although the term itself is not used the re) is caused by semantic reasons. 'Height, hair' etc. are immanent properties (Pol. cechy immanentne) and thus the attribute specifying them is simply indispensable. ${ }^{58}$

\section{Concluding Remarks}

Attributes despite being generally the non-obligatory sentence components in Korean and Polish they are very eagerly used in various registers of the spoken and written language. Giving the fact that both languages belong to different language families and are classified as different types of languages, one could presume that the parameters, according to which attributes could be classified, will differ significantly. Nevertheless as it turns out, being the agglutinative or inflected language has relatively minor influence as far as the classification of attributes is concerned, since they are very much the same.

${ }^{58}$ In 'dziewczyna o ładnych oczach' (a girl with beautiful eyes) the attribute cannot be omitted while in 'rozmowa o ładnych oczach' (the conversation about beautiful eyes) can. 
The syntactic function and semantic properties of attributes in both languages are similar. Nevertheless, the closer examination of e.g. the structure of NPs with an attribute reveals some differences. As for example, the equivalent of NP with an attribute in Polish can be a compound noun or even a simple noun in Korean (e.g. lewa ręka/ a left hand/ 왼손; zadanie domowel a homework/ 숙제 respectively). Various word classes and various linguistic units, the majority of which are common in both languages, can function as attributes. The attribute as a subordinate element of a phrase or a sentence needs to appear with the superordinate, with which it forms the endocentric construction. In Polish the head is an autosemantic word, while in Korean it can be a synsemantic one as well.

As far as the morphological structure is concerned, the determinans in NPs in Polish such as adjectives, nouns, pronouns or numerals are generally accommodated, which means that their forms, when used as modifiers, depend on the categories taken by the head, in other words their form has to agree in gender, number and case with the word the y modify. The phenomenon of syntactic accommodation in Korean is slightly different since it does not concern categories such as number, gender or case. Firstly, it is because Korean nouns do not have the category of inherent gender, which would have to be followed by an attribute. Secondly, deul (Kor. - 들) - the particle conveying the meaning of plurality is often omitted, and even if it is used, it is not attached to forms used as attributes. And finally, words used as attributes do not take the same particles as the head does. It is because some words such as e.g. so-called determiners (gwanhyeongsa, Kor. 관형사) or already mentioned gwanhyeongmyeongsa (Kor. 관형명사) do not take any particles whatsoever, while others such as adjectives and verbs when used in attributive function instead of particles take attributive endings (gwanhyeongsahyeong jeonseongeomi, Kor. 관형사형 전성어미). Even though the se endings indicate their subordination towards the head and the relation towards another attribute if it is used, they also do not reflect the gender or number of the head. Nonetheless taking e.g. the attributive or honorificative -(eu)si- (Kor. -(으)시-) endings taken by verbs and adjectives, can be compared to the regimen in Polish language, where the superordinate requires the usage of proper forms from its subordinate(s).

As far as the structure of NPs is concerned, usually one or two attributes belonging either to the same or to different word classes are 
used at the same time, although three and more can also to modify the same head. Regardless of the number and morphological structure of attributes, in Korean they always appear in pre-nominal position, while in Polish depending on their meaning (also function) and length they have either prepositional or postpositional word order, which means that in one NP they are located on both sides of the head if the qualitative and classificatory attributes are used at the same time. Nevertheless in both languages when few attributes, especially those represented by various word classes or linguistic units are used, word order reveals their sequentialization, which only to some extent can be considered as free.

This research presenting a draft classification of attributes in Korean and Polish can be treated as an introduction for further studies on this particular part of the sentence in both languages. The word order of attributes, their grammatical and semantic features etc. are only few topics, which definitely deserve more attention. Particularly noteworthy is the need for Korean-Polish and Polish-Korean comparative studies, as well as those focused on glottodidactics, taking into account e.g. the growing importance of Korean language education in Poland. The author hopes to continue the research on the subject of attributes in due time.

\section{References}

Ajdukiewicz, Kazimierz. 1965. Logika Pragmatyczna. Warszawa: PWN.

Arct, Michał. 1899. M. Arcta Stowniczek wyrazów obcych. Warszawa: M. Arcta.

https://pl.wikisource.org/wiki/M._Arcta_Słowniczek_wyrazo w_obcych/Atrybut (accessed September 18, 2016).

Bańczerowski, Jerzy; Pogonowski, Jerzy; Zgółka, Tadeusz. 1982. Wstęp do Językoznawstwa. Skrypt dla studentów studiów uniwersyteckich. Poznań: UAM.

Bąk, Piotr. 2004. Gramatyka Języka Polskiego. Warszawa: Wiedza Powszechna. 
Cetnarowska, Bożena. 2013. The Representational Approach to Adjective Placement in Polish. Linguistica Silesiana. Vol. 34: 7-22.

Fisiak, Jacek, Lipińska-Grzegorek, Maria, Zabrocki, Tadeusz. 1978. An Introductory English-Polish Contrastive Grammar. Warszawa: PWN.

Frankowska, Maria. 1982. Grupy imienne $\mathrm{z}$ determinatorem koniecznym w języku polskim. Prace Wydziału FilologicznoFilozoficznego. Vol. XXVIII No. 3. Warszawa: PWN.

Gębka-Wolak, Małgorzata. 2000. Związki linearne między składnikami grupy linearnej we współczesnym języku polskim. Toruń: Wyd. Uniwersytetu Mikołaja Kopernika.

Gołąb, Zbigniew; Heinz, Adam; Polański, Kazimierz. 1968. Stownik Terminologii Językoznawczej. Warszawa: PWN.

Grzegorczykowa, Renata. 1998. Wyktady zpolskiej sktadni. Warszawa: PWN.

Dictionary.com.

http://www.dictionary.com/browse/attribute (accessed August 13, 2016).

Merriam-Webster Dictionary. http://www.merriamwebster.com/dictionary/attribute (accessed September 16, 2016).

Jadacka, Hanna. 2005. Kultura Języka Polskiego. Fleksja, stowotwórstwo, składnia. Warszawa: PWN.

Klemensiewicz, Zenon. 1963. Zarys sktadni polskiej. Warszawa: PWN.

Klemensiewicz, Zenon. 1986. Podstawowe wiadomości z gramatyki języka polskiego. Warszawa: PWN.

Kokowski, Władysław. 1917. Krótka Składnia Języka Polskiego z ćwiczeniami i przykładami, tacznie zzasadami użycia znaków pisarskich. Wyd. VII. Warszawa: E. Wende i S-ka.

Lee, Iksop; Ramsey, S. Robert (2000) The Korean Language, NY: State University of New York Press.

Linde-Usieknieiwcz, Jadwiga. 2013. A position of classificatory adjectives in Polish. Studies in Polish Linguistics. Vol. 3, No. 3: 103-126.

Martin, Samuel L. 1992. A Reference Grammar of Korean. A Complete Guide to the Grammar and History of the Korean Language. Tokyo, Rutland, Vermont, Singapore: Tuttle Publishing. 
Mostowski, Andrzej. 1948. Logika Matematyczna. Monografie Matematyczne. Vol. 18. Warszawa.

Nagórko, Alicja. 2005. Zarys Gramatyki Polskiej. Warszawa: PWN.

Podracki, Jerzy 1997. Przydawka jako część zdania. Składnia Polska ksiązka dla nauczycieli iuczniów. Wyd. Szkolne i Pedagogiczne. Warszawa: 96-107.

Polański, Kazimierz. 2003. Encyklopedia Językoznawstwa Ogólnego. Ed. Wrocław: Ossolineum.

Ramstedt, Gustad John. 1939. A Korean Grammar. SuomalaisUgrilaisen Seuran Toimituksia. 82. Suomalais-Ugrilainen Seura. Helsinki.

Sohn, Ho-Min. 2001. The Korean Language. Cambridge: Cambridge University Press.

Swan, Oscar. 1983. First Year Polish. $2^{\text {nd }}$ Edition. Columbus: Slavica Publishers.

Szober, Stanisław. 1924. Zarys Językoznawstwa Ogólnego. Warszawa: Towarzystwa Miłośników Języka Polskiego.

Szulc, Aleksander. 1984. Podręczny Słownik Językoznawstwa Stosowanego. Warszawa: PWN.

Urbańczyk, Stanisław; Kucała, Marian. 1999. Encyklopedia Języka Polskiego. Eds. Wrocław: Zakład Narodowy im. Ossolińskich.

Weinsberg, Adam.1983. Językoznawstwo Ogólne. Warszawa: Polskie Wydawnictwo Naukowe.

Willim, Ewa. 2000. Analiza zestawień z przymiotnikiem w minimalistycznym modelu gramatyki generatywnej. Polonica, Vol. 20: 37-70.

Wójcik, Tadeusz. 1965. Zarys teorii klasyfikacji. Warszawa: PWN.

Wróbel, Henryk. 2001. Gramatyka Języka Polskiego. Kraków: Od Nowa.

Yeon, Jaehoon; Brown, Lucien. 2011. Korean - A Comprehensive Grammar -. NY: Routledge.

Zagorska-Brooks, Maria. 1975. Polish Reference Grammar. Mouton: The Hague-Paris.

Ziembiński, Zygmunt. 1995. Logika Praktyczna. Wyd. XVIII przejrzane i poprawione. Warszawa: PWN.

고영근 1989/1991. 國語形態論研究. 서울: 서울大學校出版部.

김광해, 권재일, 임지룡, 김무림, 임칠성. 1999. 국어지식탐구. 서울: 박이정. 
Anna BOROWIAK: A Draft Classification of Attributes ...

김기복. 1999. 국어의 관형어 연구. 충남대학교 대학원, 박사학논문.

김기혁. 1996. 국어문법 연구-형태. 통어론. 서울: 박이정.

김기혁. 2001. 국어학. 서울: 박이정.

김봉모. 1978 a. 매김말의 기능. 한글 제 162 호, 한글학회: 19-38.

김봉모. 1978 b. 매김말의 겹침구조 연구. 문창어문집 15집: 50-76.

김선효. 2011. 한국어 관형어 연구. 서울: 역락.

남광우, 이응백, 이을환. 1991. 국어대사전. 서울: 민중서관.

남기심, 고영근. 1985/2006. 표준국어문법론. 서울: 탑출판사.

리동빈. 1999/2004. 조선어기본 (류학생용). 김일성종합대학 출판사. 주체 88 .

리의도.1982. 매김말의 기능 - 매김 받는 임자말과의 관계를 중심으로-. 국제어문 3, 국제어문학회: 123-141.

박경자, 임병빈, 김재원, 유석훈, 이재근, 김성찬, 장영준, 한호. 2001. 응용언어학 사전. 서울: 경진문화사.

서울대학교 국어 교육 연구소. 2002/2005. 고등학교 문법. 서울: 교육 인적 자원부.

서정수. 1994. 국어문법. 서울: 뿌리깊은 나무.

오규환. 2016. "현태론적 복합 관형어 + 명사어" 구성의 어휘화에 대하여. 언어사실과 관점 38 권. 연세대학교 언어정보연구원: 195-219.

오형식. 2002. 국어문장성분 분류의 역사적 연구. 부산: 세종출판사.

이승희. 1955. 國語學概說. 서울: 민중서관.

임지룡, 이은규, 김종록, 송창선, 황미향, 이문규, 최웅환. 2005. 학교문법과 문법교육. 서울: 박이정.

정병권. 2002. 폴란드어- 한국어 사전. Ed. 서울: 한국외국어대학교 출판부: 703.

최현배. 1937/1961. 우리말본. 서울: 정음사.

한국방송통신대학교 평생교육원. 2005. 외국어로서의 한국어학. 한국방송통신대학교출판부: 137-9.

한길. 1997. 매김말로 등장하는 사람에 관한 높임법. 인문과학 연구5. 강원 대학교 인문과학연구소: 5-27.

허웅. 1983. 국어학-우리만의 오늘 어제-. 서울: 샘문화사. 